\title{
THE EXPRESSION OF MANAGERIAL LEADERSHIP IN SOCIAL SERVICE ORGANIZATIONS
}

\author{
Janina Čižikienè \\ Mykolas Romeris University, Lithuania \\ Justas Urmanavičius \\ Mykolas Romeris University, Lithuania
}

\begin{abstract}
The aim of social service organizations that provide modern social services is to give quality social services that would help a person (family) to become independent and able to integrate into society. Successful operation of organizations is ensured by the ability of managers to lead, motivate employees to achieve the set goals, and promote cooperation with stakeholders. Therefore, managerial leadership is especially important to influence the activities of the members of the organization, creating conditions for continuous improvement and cooperation. A leader must be able to bring employees into a team, evaluating achievements and facilitating social interaction between team members, and strive to continually improve employees' ability to provide individual, customer-oriented services.

The aim of the article is, based on theoretical analysis and empirical research, to highlight the peculiarities of managerial leadership in social service organizations and to define the influence of leadership in the process of providing social services to employees, service recipients, and stakeholders. The research revealed what the most important characteristics, personal qualities, and competencies of a leader in an organization are and what influence managerial leadership has when organizing and providing quality social services. The research identified the aspects of managerial leadership that would help ensure successful operation of organizations when providing effective support to those experiencing exclusion in the community.
\end{abstract}

Keywords: leadership, managerial competencies, social service organizations, social services.

\section{Introduction}

Social inequalities, various social problems (such as poverty, social and health diseases, crime, etc.), and the resulting need to help weaker members of society with various social problems have always existed in state societies (Blakemore \& WarwickBooth, 2013; Ščepkauskaitė, 2013; Vanagas \& Čižikienė, 2015; Čižikienė \& Urmanavičienè, 2018). Therefore, people are developing and improving social security systems. They are looking for effective ways and means to provide the most effective assistance to a person who has lost the ability to act independently and effectively in society while ensuring that every member of society has access to some help and support. One of the most widely - used 
instruments for providing assistance and ensuring proper arrangement and accessibility of social services is social inclusion. In social service organizations, social programs are generally coordinated and delivered. Researchers from different countries study the activities of organizations and the peculiarities of social services provided in EU countries (Esping-Andersen, 1990; Lethbridge, 2005; Penna \& O'Brien, 2006; Harpur, 2012; Bode et al., 2013; Greve \& Sirovátka, 2014; Bode, 2017; Koprić et al., 2017; Wollmann \& Marcou, 2017; Marimon et al., 2019; Abrahamson, Greve, \& Boje, 2019). It should be noted that researchers regularly examine the problems of the framework of social services and organizations providing these services, they attempt to base their activities on certain principles, show how it is possible to evaluate the quality of activities and their efficiency in mixed market conditions (Vanagas \& Čižikienè, 2015; Mažeikienè, Naujanienė, \& Ruškus, 2014; Andrews \& Jilke, 2016; Bode, 2017; Evers et al., 2019; Čižikienè, 2020). In social service organizations, however, there is a lack of studies on leadership issues.

The aim of the article is to unveil the characteristics of the leadership expression of the leaders of social service organizations to achieve good performance results and ensure the quality of services. To achieve the goal, the following tasks are set: to describe the leadership of managers providing social services within the scope of transformations in the social services sector; To define the principles that establish the leadership of social service provider organizations; to analyze the preconditions determining the leadership of managers in organizations providing social services.

\section{Aspects of Managerial Leadership in the Field of Social Services}

When evaluating the leadership of social service managers, it is appropriate to consider the developments in the social services sector that have influenced leadership change. Researchers (Dunajevas, 2009; Blakemore \& Warwick-Booth, 2013; Koprić, Wollmann, \& Marcou, 2017; Wollmann \& Bönker, 2018; Wollmann, 2018) identify these stages of development of the social service system: the first stage is linked to the emergence of social security systems in Germany and the affect of the activities of non - governmental organizations within the field of social services. The second stage is called the state's welfare stage, it started after the Second World War and there was a tendency to transfer the responsibility of personal social problems to the communities and the influence of public sector institutions to solve. The third development phase, which started after 1970, is marked by a trend towards the privatization of social risks and is based on the idea of mixed market for social services. Empirical research confirms (Williams \& Glisson, 2014; Kremer, Villamor, \& Aguinis, 2019) that the social context is crucial for the successful dissemination and 
implementation of innovation because the social environment that surrounds an individual, shape his perception, behavior, attitudes, it influences innovation and implementation (DiMaggio, 1997; Hatch, 2004; Rogers, 2003; Scott, 2013). The effect of the social context therefore influences actions of the organizational manager's as a leader, his development and formation of the purpose of activity. (DiMaggio, 1997; Lawler \& Bilson, 2013; Healy, 2014). It also explains the leadership differences in paradigm shifts and attitudes towards the quality of services provided. The social context of these organizations is stakeholderdependent and related to the individual needs of the consumers of services and the results achieved (Lawler, 2007; Aarons et al., 2012; Healy, 2014; Michailakis \& Schirmer, 2014). Tracing the development of leadership theories, it can be seen that leadership was determined by a single choice, such as personal characteristics, behavioral style, situation characteristics, and so on. Understanding the shortcomings of a one-sided approach, a combination of leadership models was introduced, encompassing several concepts of factors such as personal-situational, behavioral-situational, personality-behavioral. Modern leadership is dominated by a systemic approach that encompasses an individual's personality traits, his or her behavior, and the situation in which he or she is realized. Thus, leaders of social service organizations had to choose leadership models that best matched the organization's concept and mission to help sure the well-being of the individual and streamline the organization (Chang, Shih, \& Liu, 2019; Zhang, Liu, \& Wang, 2020). The most appropriate models were those that emphasized the following factors: participation, value creation in the organization's goals, and joint decision-making. Stoner et al., 2006 distinguish the "four C" model that reveals the results of management in the human resource management process, in which the expression of leadership is important: commitment, competence, congruence, cost-effectiveness. These components of the model allow us to explain the guidelines of managerial leadership in terms of commitment, competence, congruence, and cost-effectiveness (Chlivickas, Papšienė, \& Papšys, 2010; Chlivickas \& Luckutè, 2016; Brunetto \& Beattie, 2020). The ever-changing social environment poses new challenges for the social services sector, society, community, so the manager must not only perform his / her direct management and leadership functions but also become an organizer and innovator of management practice (Lynch-Cerullo \& Cooney, 2011; Carnochan et al., 2019; Hwang, 2019). Thus, managerial leadership was determined by the new public management factors in the social services sector: service commercialisation and increased competition in the service sector, total standards of quality management, local administrative control and transparency, legislative reforms accepted by the government, evidence-based organizational social work activities and technical developments (Carnochan et al., 2014; Bode, 2017; Wathne, 2020; Hansen et al., 2020) 
Čižikienè \& Urmanavičius, 2021. The Expression of Managerial Leadership in

Social Service Organizations

\section{Principles that Determine the Leadership of the Leaders in Organizations Providing Social Services}

Successful expression of leadership is closely linked to the progress of social cohesion in society. The participation and involvement of community members in the social services sector in volunteering is a necessary factor in promoting and increasing the social, civic, and economic activity of individuals. It is based on mutual understanding, common values, and goals of community members. Leadership must include social cohesion concept, which is characterized as the development of conditions for the environment. According to this concept, individuals, groups, or communities must be willing to trust and work together to achieve common goals, provide support and assistance and help to solve problems. Close links between social cohesion development and external/internal environment could help to address social exclusion in society and community.

Based on the insights of the authors of scientific literature (Adams et al., 2009; Raipa, 2011; Ife, 2012; Gvaldaite et al., 2014; Rimkus, 2015; Fook, 2016; Gečienė \& Raišienė, 2019; Čižikienė, 2020), EU strategy papers and legislation, the authors of the article single out the following principles that determine the leadership of social service providers:

Principle of social justice: The notion of social justice is based on the idea that social services are available to anyone who needs them. Receiving such assistance shall not be impeded by any circumstance, nor by the capacity of the person to pay for services;

The principle of participation: The principle of participation means that the manager is involved in the productive assistance process, involving the recipients and stakeholders;

The principle of solidarity: The principle of solidarity means that the manager is responsible for his own and others well-being by contributing to those who can not take care of themselves;

Principle of cooperation: The principle of cooperation means that the manager when planning the organization and protocol of social services, must rely on the cooperation of social services, municipal and state institutions, and social partners;

Principle of complexity: Family members and relatives participate in the process of providing social services because a person's social problem always affects his / her family and close environment. Family members also need help in getting rid of negative emotions, providing support;

Eligibility: Eligibility is defined as ensuring that the needs and priotities of an individual and his or her family are assessed and that social services are organized and provided with a proper assessment of their needs; 
Principle of universality: The principle of universality states that services must be combined with other support measures, such as social assistance in cash, protection of children's rights, education and upbringing, employment, health care, provision of social housing, special assistance measures;

Principle of availability: The principle of availability means that services must be provided to a person as close as possible to his or her place of residence. This principle defines the significance of the community's role in the provision of social services;

Principle of efficiency: The principle of efficiency is understood as the ability to ensure that services in a social service organization are managed and delivered to achieve good results and rational use of available resources;

Operational management: The activities of social service organizations depend on the available financial, human, and time resources, which are rather limited. So the continuous development of social services must be encouraged, coherent strategies must be developed at local, regional, and national levels to achieve universal service availability, quality, and financial stability, given that social problems are often complex and therefore impossible to solve in the short term through fragmented activities;

Continuity principle: The principle of continuity means the aim of ensuring the stability of the organization's activities, as services must be organized in such a manner that they can be continued and, if necessary, assisted for the person and his family;

Ethical principles: While providing social services, security of rights needs to be assured, interests, and dignity of each person with due respect;

Principle of quality assurance: Ensuring the quality of the activities of a social services organization and the continuity and consistency of social services is considered to be a general principle in all member states of the European Union;

Partnership principle: This principle means that the provision of support is a collective process involving stakeholders, social partners, civil society organizations, the community, involving volunteers;

Accordingly, it can be noted that the principles that define leadership are based on the well-being of the recipient of the service and the evaluation of employee needs and interests. The successful operation of the organization can be ensured only if the service recipient himself is involved in the whole process of assistance and support not only as a recipient of social services but also as an active aid planner, organizer, and evaluator. The principles discussed also indicate that social service organizations cannot be closed or work alone, so every social service organization needs to have social partners, which can undoubtedly be related to the ideas of the new public management and private sector provisions that are transferred to the public sector. The principles discussed to make it possible to highlight certain general attitudes inherent in the leadership of social 
service organization leaders. The following provisions can be distinguished: firstly, respect for the person and his individuality and recognition of differences, understanding that the provision and performance of social services must not be influenced by any features or peculiarities of the life of a person; secondly, recognizing that no assistance to a person will be effective if the person and his or her family members do not engage actively in the assistance process themselves; thirdly, leading managers must be directed by foundational humanistic values such as solidarity, respect for human rights, honesty, compassion, tolerance, etc.fourth, highlight the value of leadership in the society, believing that integration into society is much more efficient if the individual is assisted by members of the community who can contribute to the provision of social services because of the resources available (e.g., volunteering). Leadership emphasizes equal opportunities for individuals, and Organizational leaders are focusing on building a social service structure founded on democratic principles. They emphasize citizenship, evaluation more agile service delivery and quality service, and self-control, establishing a stable management environment. Analyzing the scientific literature, it should be noted that researchers confirm the distinctiveness of social service organizations and argue that this distinctiveness must be repeated in the process of organization and leadership (Lynch-Cerullo \& Cooney, 2011; Sullivan, 2016; Gečienè \& Raišienè, 2019), because the social services sector is based on values that promote human dignity, help combat discrimination, social stigma, and provide services to lessen suffering and social exclusion. Based on the scientific literature (Hasenfeld, 2010, 2015; Shanks et al., 2013; Hopkins et al., 2014; Shanks, 2016; Sullivan, 2016), it is possible to single out the determinants of leadership in social service managers that define leadership expression. In this case, the well-being of social service users and the motivation and needs of employees, social context, social harmony and community should be mentioned. Factors that determine the effectiveness of managerial leadership are also singled out: the stakeholders, management trends, and economic context

Consequently, leadership is geared to the well-being of service users and follows the concept of an 'open door', where service users are free to interact with the manager, make comments and share their concerns. Also, effective leaders need to not only think about productivity and efficiency but also take care of employee morale and satisfaction, consider their needs. It is necessary to emphasize that customer-centred leadership must involve service users and employees in the assessment of the organization's activities, make decisions together, take into account their suggestions and position on the issues under consideration. Recipient-centred leadership embodies the ideals of social work and reflects the concept of social integration concerning empowering the individual (family). Therefore, the leadership of social organization leaders is crucial in the social change process to ensure the organization's effectiveness and 
efficiency. The key purpose of social leaders focused on social work principles and a humanistic approach to leadership from the spectrum of other service sectors must be the well-being of the user of the service.

\section{Research Methodology}

To reveal the factors of leadership style in organizations providing social services, a qualitative study was selected (Bitinas, Rupšienè, \& Žydžiūnaitė, 2008; Silverman, 2015; Žydžiūnaite \& Sabaliauskas, 2017). Qualitative research is applied to the analysis of little-researched topics - it helps to find new ideas and perspectives on how to better organize activities and achieve the intended goals (Bitinas, Rupšienè, \& Žydžiūnaitè, 2008). Qualitative data analysis is revealed through experiences, meanings, and processes. Results are interpreted according to the meanings assigned to phenomena (Silverman, 2015).

The goal of the study is to convey managerial leadership in social services organizations. The study aims to reveal the characteristics of the expression of management leadership in social service organizations. Empirical research objectives: 1) to survey managers' opinions, which would help to determine the expression of managers' leadership in organizations providing social services; 2) to evaluate the preconditions determining the leadership of managers in organizations providing social services. Issues: What are the main characteristics of a successful SSO leader? What leadership style, traits, and qualities do you choose in your organization? How does your leadership affect the organization's employees and service users?

The interviews with the SSO (social service organization) executives were chosen because the executives have expert knowledge of the problem under investigation and their current duties allow them to speak on behalf of a professional activity or organization. Semi-structured interviews were chosen for the interviews of managers, it allowed to obtain detailed, systematized data, and the interview itself is informal, it takes place more in the form of dialogue (Rupšienè, 2007; Maxwell, 2008). Five SSO executives were interviewed through a semi-structured interview. Selected criteria for informants: management experience of at least 5 years, professional experience of social work at least 7 years (E1- management experience 5 years, work experience 15 years; E2management experience 10 years, work experience 23 years; E3- management experience 7 years, work experience 12 years; E4- management experience 10 years, work experience 16 years; E5 management experience 6 years, work experience 10 years). It should be stressed that respondents decided to take part in the study when they were told of the study's ethics: the study course; the discretion and confidentiality of the data provided. The obtained data will be presented in such a manner that particular informant cannot be identified. Research limitations: 
Čižikiene \& Urmanavičius, 2021. The Expression of Managerial Leadership in

Social Service Organizations

the study was conducted in Vilnius county and it may not accurately reflect the general situation in all organizations, therefore preliminary data obtained during this study are presented. To obtain more accurate and reliable information, more detailed quantitative studies are required.

\section{Research Results}

All interview experts pointed out that the head of the SSO must have a vision of the organization if it wants to work effectively and take stakeholders into account: Vision, because you must know what to accomplish (E1),; The manager must have a clear vision, know the priorities of what he wants to achieve and be flexible, have a lot to anticipate (E5); Clear vision and the ability to pursue a vision by motivating staff (E3); It is a clear vision, a mission that the whole team contributes to, it is to put together a team in the sense of trusting everyone and revealing the benefits, but the meaning of the vision needs to be shown (E4). It can be argued that an organization's outlook is a very important subcategory that can provide a vision of the future, about its place as a leader and its relationship to the internal and external environment of the organisation, i. y. to model the system of his views and values, the system of competencies and abilities, anticipating future development in the structure of the social system. In order to respond effectively to a changing external environment, a manager needs to build on a vision when implementing a strategy and anticipating future organizational goals (Ejimabo, 2015).

As a key leadership style, informants cited democratic governance in the organization as an effort to involve all participants in the organization in decisionmaking, unleash the potential of each employee, and engage in ongoing change: The manager must be like the leader and still be invisible ... in my opinion, a manager is good when an organization is running successfully at a time when everyone is already involved in the action, no one is collapsing, no disasters are happening, and all employees know what to do ... that is the most significant thing (E2); Because every change brings transformations ... it's important to want to change yourself and then already show employees it, involve them by calming and understanding them (E5). The study confirms that a democratic style of governance that promotes mutual assistance, cooperation, and the involvement of employees and service users in decision-making is the most appropriate in social service organizations.

By distinguishing the type of leadership, the study participants clearly emphasize transformational leadership, and the drive for change encourages managers to work effectively in the organization and their influence motivates employees and the environment to adopt new managerial practices. According to informants, the head of the SSO chooses transformational leadership, because 
then it creates a connection with employees, service recipients, increases and promotes the motivation of followers to take responsibility to work together and achieve the intended goal: Anyway, transformational leadership is used, for the most part. After all, things change in certain circumstances certain things, the manager working in the SSO covers a very large range of work (E2); And not everyone likes change because not everyone likes the decisions they make, it needs to grab everyone and inspire them to move forward (E4); Encouraging team development, involving members of the organization in planning, motivating and inspiring (E1). The responses suggest that SSO executives, try to consider what can help inspire employees, see the advantages of communication, and therefore seek to see, evaluate, and persuade them to engage in the process. Most of the informants agreed that in order to achieve successful goals, it is necessary for employees to see the manager's efforts, as well as to show attention and confidence that the intended result will be achieved, and the efforts made will change the organization.

The study revealed that managers place a strong emphasis on the values of team and teamwork, as the delivery of social services involves collaboration and coordination of tasks within a team. Respondents indicated: Ideal leadership is team-based, but whether it always succeeds here is the question (E3); You have to work already in a team, team leadership, look together (E5); I accept team leadership more, I mentioned before that without a team leader there is no one, you will not achieve anything without a team ... one is not a soldier in the field if you do not have a good team you will not achieve anything (E1). The scientific literature (Braun et al., 2013) emphasizes the orientation of transformational leaders towards teamwork but faces challenges in reconciling individual personal goals and the desired mission in the process of building an atmosphere of trust and support, communication, task control, and interpersonal conflict resolution. Therefore, transformational leadership has an influence on the organisation and responsibility of teamwork, involving individuals and creating a teamwork environment in which one can achieve the desired change by showing individual concern and respect.

The goal of the study was to decide which management competencies have an important effect on the SSO's effective leadership. To find out the manager to have the skills to help achieve the strategic objectives of the company. Respondents singled out personal, social, professional competencies.

Respondents consider personal competencies to be the abilities that determine the desire to take responsibility in an organization and include emotional self-understanding by recognizing their emotions and understanding their impact as a leader in an organization: Such personal qualities, very fast thinking and that's a trait of mine, I think very fast, and others do not keep up with me. I already understand that then I demonstrate that it is not a matter worth 
noting. Man needs to set out the problem because I have already understood it, but man needs to set everything out (E2); accurate self-awareness, knowledge of one's strengths and limits: Excessive impulsivity interferes, again this personal trait is ... maybe I don't allow employees to express themselves fully ... and there is one employee slower, another faster (E4); and self-confidence based on selfesteem and personal possibilities: To the leader himself as a person and you just realize that sometimes you are like a blacksmith who can tilt people's lives in a certain direction ... and your decisions are very fateful (E5); A leader's calm, stubbornness, control of emotions is paramount (E1).

Social competencies were identified by respondents as skills that determine the management of social relations and the maintenance of appropriate communication in the system. They singled out that understanding both, the external and internal environment is important for managing the relationship, on which the success of the deployment, collaboration with stakeholders, and team involvement in the service delivery process depends. Social awareness includes empathy for the service user, the attitude of the employees, the perception of emotions: These qualities, sometimes very much and that knowledge and that ability, emotion controlv(E2); Because the manager has to be very competent, have a lot of knowledge, but also keep in mind that these are people with their own experiences and lives (E4).

Professional competencies in social work are necessary for the head of the SSO, as respondents stated that managers need to be based on social values and have professional competencies related to social work, and knowledge of the social service organization. Then successful leadership is possible: The supervisor must necessarily be a social worker and know the specifics and competencies of social work (E1); Leadership with social work practices has grown (E3). It should be emphasized that all respondents have the qualification of a social worker and at least five years of experience in the SSO, so they all agreed that to lead the SSO a person needs to have a social work qualification and understand the specifics of the social services sector: We know, for example, when it comes to a completely non-social leader, it is very difficult for him to comprehend this system and very difficult to understand (E2); Very well and you should move from the lowest level in the office or work, take a few different jobs to understand how it is and what the recipients of the services are, it should go in that direction (E1); Let's say those directors and managers who have a pedagogical degree ... where is a lack of social work and managerial knowledge, that willingness to change and accept challenges, well, we need competencies (E5). 


\section{Conclusions}

The theoretical and empirical analysis of the expression of managerial leadership revealed that successful activities of social service organizations are focused on helping to solve social problems in society and community, therefore managerial leadership of organizations is influenced by social cohesion processes and principles which are based on respect to the individual and his/her uniqueness, recognizing that individual or lifestyle characteristics should not affect the provision of quality social services. In the process of social transformation, managerial leadership of organizations is important in ensuring the efficiency and effectiveness of the organization, but the main goal of social leaders is defined to achieve the well-being of social service recipients and is based on democratic principles and humanistic values.

The research revealed that managers, understanding the mission of a social service organization, have a vision of how to work effectively, encourage and involve all members of the organization in the operational process. In making strategic changes, managers have insight into the needs of social policy, and, in response to the changing external and internal environment of the organization, they look for an appropriate leadership strategy to help achieve the goals and mission of the organization. Based on the research results, it can be stated that managers choose a democratic management style that encourages teamwork and cooperation, and helps employees and service recipients to get involved in decision-making about the provided quality social services. The research showed that the respondents single out transformational leadership, which is determined by the pursuit of change and opportunities to apply new social work practices in the organization. It was found that the personal, social, and social work professional competencies, singled out by managers, are based on social values and define leadership expression in the social service sector.

\section{References}

Aarons, G. A., Fettes, D. L., Sommerfeld, D. H., \& Palinkas, L. A. (2012). Mixed methods for implementation research: application to evidence-based practice implementation and staff turnover in community-based organizations providing child welfare services. Child maltreatment, 17(1), 67-79.

Abrahamson, P., Greve, B., \& Boje, T. (2019). Welfare and families in Europe. Routledge.

Adams, R., Dominelli, L., \& Payne, M. (2009). In R. Adams, L. Dominelli, M. Payne (Eds.), Practising social work in a complex world. Macmillan International Higher Education.

Andrews, R., \& Jilke, S. (2016). Welfare states and social cohesion in Europe: Does social service quality matter? Journal of Social Policy, 45(1), 119-140.

Bitinas, B., Rupšienè, L., \& Žydžiūnaitè, V. (2008). Kokybiniu tyrimu metodologija. Klaipėda: SMK. 
Čižikiene \& Urmanavičius, 2021. The Expression of Managerial Leadership in

Social Service Organizations

Blakemore, K., \& Warwick-Booth, L. (2013). Social Policy: An Introduction. Mcgraw-Hill Education (UK).

Bode, I. (2017). Social services in post-industrial Europe: an incomplete success story and its tragic moments. In Social Services Disrupted. Edward Elgar Publishing.

Bode, I., Champetier B., \& Chartrand S. (2013). Embedded marketization as transnational path departure. Assessing recent change in home care systems comparatively. Comparative Sociology, 12(6), 821-850.

Braun, S., Peus, C., Weisweiler, S., \& Frey, D. (2013).Transformational leadership, job satisfaction, and team performance:A multilevel mediation model of trust. The Leadership Quarterly, 24(1), 270-283.

Brunetto, Y., \& Beattie R. (2020). Changing role of HRM in the public sector. Public Management Review, 22(1), 1-5.

Carnochan, S., McBeath, B., Chuang, E., \& Austin, M. J. (2019). Perspectives of public and nonprofit managers on communications in human services contracting. Public Performance \& Management Review, 42(3), 657-684.

Carnochan, S., Samples, M., Myers, M., \& Austin, M. J. (2014). Performance measurementchallenges in nonprofit human service organizations. Nonprofit and Voluntary Sector Quarterly, 43(6), 1014-1032.

Chang, Y. Y., Shih, C. H., \& Liu, C. J. (2019). Decision-Making of Enterprise Leaders From the Perspective of Organizational Neuroscience. Management, 7(4), 361-371.

Chaudoir, S. R., Dugan, A. G., \& Barr, C. H. (2013). Measuring factors affecting implementation of health innovations: a systematic review of structural, organizational, provider, patient, and innovation level measures. Implementation science, 8(1), 22.

Chlivickas, E., \& Luckutè, R. (2016). Viešojo sektoriaus valdymas:žmogiškujų išteklių sistemos modernizavimas. Public Administration, 3(51), 4.

Chlivickas, E., Papšienè, P., \& Papšys, A. (2010). Human resources: Strategic management aspects. Business, Management and Education, 8(1), 51-65.

Čižikienè, J. (2020). Vadovu lyderystè pasirenkant diegti Europos socialiniu paslaugu kokybès užtikrinimo sistema (Doctoral dissertation, MRU).

Čižikienè, J., \& Urmanavičienè, A. (2018). The aspects of provision of social services considering the social exclusion dimensions in the context of rational choice theory. Eurasian journal of social sciences, 6(1), 29-36.

DiMaggio, P. (1997). Culture and cognition. Annual review of sociology, 23(1), 263-287.

Dunajevas, E. (2009). Socialinių paslaugu sistemos raida gerovès pliuralizmo požiūriu. Sociologija. Mintis ir veiksmas, (02), 120-129.

Ejimabo, N. O. (2015). An approach to understanding leadership decision making in organization. European Scientific Journal, 11(11).

Esping-Andersen, G. (1990). The Three Worlds of Welfare Capitalism. Princeton: Princeton University Press.

Evers, A., Haverinen, R., Leichsenring, K., \& Wistow, G. (Eds.). (2019). Developing qualityin personal social services: Concepts, cases and comments. Routledge.

Fook, J. (2016). Social work:A critical approach to practice. Sage.

Gečienè, J., \& Raišienè, A. G. (2019). Factors for strengthening the organizational resilience by the case of organizations providing social services. Socialine teorija, empirija, politika ir praktika, 19, 71-86.

Greve, B., \& Sirovátka, T. (Eds.). (2014). Innovation in Social Services: The Public-privateMix in Service Provision, Fiscal Policy and Employment. Ashgate Publishing, Ltd.. 
Gvaldaitė, L., Švedaitė-Sakalauskè, B., \& Buzaitytė-Kašalynienė, J. (2014). Vadovavimas socialiniam darbui:pasekmès darbuotojams ir profesinei veiklai. Tiltai, (2), 109-125.

Hansen, M. B., Lindholst, A. C., \& Greve, C. (2020). Organizing Marketization. In Marketizationin Local Government. Palgrave Macmillan, Cham.

Harpur, P. (2012). Embracing the new disability rights paradigm: The importance of the Convention on the Rights of Persons with disabilities. Disability \& Society, 1(27), 1-14.

Hasenfeld, Y. (2015). What exactly is human services management? Human service organizations: Management. Leadership \& Governance, 39(1), 1-5.

Hasenfeld, Y. (Ed.). (2010). Human services as complex organizations (2nd ed.). Newbury Park, CA: SAGE.

Hatch, M. J. (2004). Dynamics in organizational culture. Handbook of organizational change and innovation.

Healy, K. (2014). Social work theories in context: Creating frameworks for practice. Macmillan International Higher Education

Hopkins, K., Meyer, M., Shera, W., \& Peters, S. C. (2014). Leadership challenges facing nonprofit human services organizations in a post-recession era. Human Service OrganizationsManagement, Leadership \& Governance, 38(5), 419-422.

Hwang, K. (2019). Understanding complexity of administrative reform. International Journal of Organizational Analysis, 27(3), 630-643.

Ife, J. (2012). Human rights and social work: Towards rights-based practice. Cambridge University Press.

Koprić, I., Wollmann, H., \& Marcou, G. (Eds.). (2017). In I. Koprić, H. Wollmann \& G. Marcou (Eds.), Evaluating reforms of localpublicand social services in Europe: More evidence for better results. Springer.

Kremer, H., Villamor, I., \& Aguinis, H. (2019). Innovation leadership:Best-practice recommendations for promoting employee creativity, voice, and knowledge sharing. Business Horizons, 62(1), 65-74.

Lawler, J. (2007). Leadership in social work: A case of caveat emptor? British Journal of Social Work, 37(1), 123-141.

Lawler, J. \& Bilson, A. (2013). Social Work Management and Leadership: Managing Complexity with Creativity. New York, Routledge.

Lethbridge, J. (2005). Changing care policies in Europe. London:Public Services International Research Unit.

Lynch-Cerullo, K., \& Cooney, K. (2011). Moving from outputs to outcomes: A review of the evolution of performance measurement in the human service nonprofit sector. Administration in Social Work, 35(4), 364-388.

Marimon, F., Melão, N., \& Bastida, R. (2019). Motivations and benefits of quality management systems in social services: mediation of the implementation process. Total Quality Management \& Business Excellence, 1-26.

Maxwell, J. A. (2008). Designing a qualitative study. The SAGE handbook of applied social research methods, 2, 214-253.

Mažeikienè, N., Naujanienė, R., \& Ruškus, J. (2014). What is mixed in welfare mix? Welfare ideologies at stake in the Lithuanian case of social service delivery. European Journal of Social Work, 17(5), 641-655.

Michailakis, D., \& Schirmer, W. (2014). Social work and social problems: A contributionfrom systems theory and constructionism. International Journal of Socialwelfare, 23(4), 431-442. 
Čižikienè \& Urmanavičius, 2021. The Expression of Managerial Leadership in

Social Service Organizations

Penna, S., \& O'Brien, M. (2006).What price social and health care? Commodities, competition and consumers. Social Work \& Society, 4(2), 217-231.

Raipa, A. (2011). Naujojo viešojo valdymo indikatorių diagnozavimo galimybès. Viešoji politika ir administravimas, 10(2), 167-182.

Rimkus, V. (2015). Neapibrèžtumo aspektai socialiniame darbe. Tiltai, (1), 99-113.

Rogers, E. (2003). The Diffusion of Innovations. Fifth Edition. The Free Press, New York.

Rupšienè, L. (2007). Kokybinio tyrimo duomenu rinkimo metodologija. Klaipėda: KU.

Ščepkauskaitè, K. (2013). Socialinių paslaugų administravimas: Šiaulių rajono savivaldybès atvejis. Ekonomikos ir vadybos aktualijos, 277-285.

Scott, W. R. (2013). Institutions and organizations:Ideas, interests, and identities. Sage publications.

Shanks, E. (2016). Managing social work:Organisational conditions and everyday work for managers in the Swedish social services (Doctoral dissertation, StockholmUniversity).

Shanks, E., Lundström, T., \& Bergmark, Å. (2014). Embedded in practice? Swedish social work managers on sources of managerial knowledge. Human Service Organizations: Management, Leadership \& Governance, 38(5), 435-447.

Silverman, D. (2015). Interpreting qualitative data. Sage.

Stoner, J. A. F., Freeman, R. E., \& Gilbert, D. R. (2006). Vadyba. Kaunas: Poligrafija ir informatika.

Sullivan, W. (2016). Leadership in Social Work: Where are We? Journal of Social Work Education, 52(1), 51-61.

Vanagas, R., \& Cizikiene, J. (2015). The peculiarities of social service organizations development. International journal of academic research, 7(1), 24-30.

Wathne, C. T. (2020). New Public Management and the Police Profession at Play. Criminal Justice Ethics, 1-22.

Williams, N. J., \& Glisson, C. (2014).Testing a theory of organizational culture, climate and youth outcomes in child welfare systems: A United States national study. Child Abuse \& Neglect, 38(4), 757-767.

Wollmann, H. (2018). Public and personal social services in European countries from public/municipal to private-and back to municipal and "third sector" provision. International Public Management Journal, 21(3), 413-431.

Wollmann, H., \& Bönker, F. (2018). Evaluating personal social services in Germany. In Evaluating Reforms of Local Public and Social Services in Europe. Palgrave Macmillan, Cham.

Zhang, H., Liu, Z., \& Wang, Y. (2020). How transformational leadership positively impacts organizational citizenship behavior in successful Chinese social work service organizations. Nonprofit Management and Leadership, 30(3), 467-485.

Žydžiūnaitė, V., \& Sabaliauskas, S. (2017). Kokybiniai tyrimai. Principai ir metodai. Vilnius: Vaga. 